\title{
PENGARUH PERCEIVED EASE OF USE DAN PERCEIVED USEFULNESS TERHADAP KEPUTUSAN PENGGUNAAN APLIKASI TOKOPEDIA MELALUI TRUST SEBAGAI VARIABEL INTERVENING
}

\author{
Rizky Ramadhany Sito Putri \\ Universitas Negeri Surabaya \\ rizkyramadhany3@gmail.com \\ Sri Setyo Iriani \\ Universitas Negeri Surabaya \\ srisetyo@unesa.ac.id
}

\begin{abstract}
The development of technology-based businesses has increased as a result of the Covid-19 pandemic. One of them is e-commerce as an online shopping service provider. The purpose of this study is to analyze and discuss the effect of perceived ease of use, perceived usefulness, and trust in actual system use decisions. Respondents in this study were people aged 15-39 who had used the Tokopedia application in 2020 and accessed it via smartphone. The sample used was 200 respondents. The sampling method using non-probability sampling, and the sampling technique is judgemental sampling. The data collection techniques using an online questionnaire and analyzed using Path Analysis in AMOS program 23 version. This study found that perceived ease of use has a positive and significant effect on trust and actual system use. Perceived usefulness has a positive and significant effect on trust but does not affect actual system use.Moreover, trust has a positive and significant effect on actual system use. Furthermore, the result was found that perceived ease of use and usefulness positively affect actual system use with trust a mediating variable. Based on these result, it is recommended that Tokopedia could improve the easiness and the usefulness of their application system while keep maintaining the trust of its users.
\end{abstract}

Keywords: actual system use; e-commerce; perceived ease of use; perceived usefulness; trust.

\section{PENDAHULUAN}

Pandemi covid-19 yang terjadi awal tahun 2020 hingga saat ini berdampak pada berbagai aspek kehidupan masyarakat. Tingginya tingkat penularan virus menjadi alasan pemerintah untuk memberlakukan beberapa kebijakan seperti pembatasan kunjungan tempat umum dan pemberlakuan social distancing. Keadaan tersebut mendorong perusahaan yang terdampak dan masyarakat untuk dapat beradaptasi dengan cepat. Salah satu bentuk adaptasi tersebut adalah terjadinya perubahan pada pola belanja masyarakat. Keterbatasan interaksi antar individu membuat masyarakat lebih memilih untuk beralih melakukan pemenuhan kebutuhannya melalui media low contact atau online (Bisnis.com, 2020). Menurut survei yang dilakukan Badan Pusat Statistik pada tahun 2020, sekitar $31 \%$ responden mengalami peningkatan aktivitas belanja online selama pandemi dengan generasi millenial sebagai penyumbang kuantitas tertinggi (Bps.go.id, 2020).

Terjadinya perubahan pola belanja masyarakat memberikan dampak positif bagi media belanja berbasis online seperti e-commerce. Menurut survei Katadata.co.id (2020) sistem e-commerce sebagai media low contact atau online untuk berbelanja mengalami peningkatan hingga $23 \%$ selama pandemi. Peningkatan transaksi e-commerce ini dicatat oleh Bank Indonesia dua kali lipat lebih tinggi dari tahun sebelumnya dengan jumlah 80 juta transaksi pada tahun 2019 menjadi 140 juta transaksi pada tahun 2020 (Cnnindonesia.com, 2020). Nilai transaksi meningkat dari Rp205,5 triliun pada 2019 menjadi Rp266,3 triliun pada 2020 (Katadata.co.id, 2021). Sistem e-commerce yang menawarkan layanan berbelanja online di Indonesia antara lain: Tokopedia, Shopee, Bukalapak, Lazada dan Blibli.

Jumlah pengguna layanan dari beberapa aplikasi e-commerce tersebut pada tahun 2019 antara lain: Tokopedia sebesar 411,5 juta pengguna, Shopee sebesar 294,5 juta pengguna, Bukalapak sebesar 286,8 juta pengguna, Lazada sebesar 157,9 juta pengguna dan Blibli sebesar 118,7 juta pengguna 
Rizky Ramadhany Sito Putri \& Sri Setyo Iriani. Pengaruh Perceived Ease of Use dan Perceived Usefulness terhadap Keputusan Penggunaan Aplikasi Tokopedia melalui Trust sebagai Variabel Intervening

(Iprice.co.id, 2021). Besarnya jumlah pengguna pada aplikasi Tokopedia pada tahun 2019 tersebut menjadikan aplikasi Tokopedia sebagai aplikasi e-commerce dengan pengguna tertinggi di Indonesia. Aplikasi Tokopedia sendiri merupakan pelopor perusahaan e-commerce yang telah berkembang menjadi salah satu industri internet di Indonesia dengan pertumbuhan tercepat sejak didirikan pada tahun 2009 (Lestari \& Widyastuti, 2019). Namun meski demikian, ketika pandemi terjadi pada tahun 2020 dan penggunaan e-commerce untuk berbelanja online dari masyarakat meningkat, pengguna aplikasi Tokopedia diketahui justru mengalami penurunan menjadi 355,5 juta pengguna. Jumlah ini berbanding cukup jauh dari pesaingnya, seperti aplikasi Shopee yang meningkat menjadi 390,7 juta pengguna dan memimpin pada tahun 2020 (Iprice.co.id, 2021).

Penurunan pengguna pada aplikasi Tokopedia terjadi tidak lama setelah diketahui bahwa 90 juta data pengguna pada aplikasi tersebut mengalami pencurian dan dijual oleh sekelompok peretas Shiny Hunters pada awal tahun 2020 (Katadata.co.id, 2020). Data yang tercuri diantaranya: nama, email dan kata sandi pengguna (Katadata.co.id, 2020). Pencurian data pengguna pada sistem belanja online kemudian dikhawatirkan dapat menimbulkan persepsi negatif dari kepercayaan pelanggan dan penurunan reputasi akan keamanan aplikasi. Kepercayaan sendiri menurut Turban et al. (2010:187) adalah salah satu dari beberapa faktor yang dapat memengaruhi pengambilan keputusan pembelanjaan secara online. Jika kualitas pada perusahaan dinilai masih kurang, maka konsumen cenderung merasa ragu ketika hendak melakukan pembelanjaan secara online.

Menurut Turban et al. (2010:187) dalam berbelanja online, untuk mencapai kesepakatan antara pelanggan dan penjual yang tidak dapat bertemu secara langsung, kepercayaan merupakan faktor penting dalam memengaruhi pengambilan keputusan pelanggan. Terjadinya perubahan pada pola belanja masyarakat dengan lebih memilih untuk berbelanja menggunakan media online seperti sistem e-commerce, menunjukkan bahwa sistem e-commerce dipercaya menjadi pilihan bagi masyarakat untuk memenuhi kebutuhannya dibandingkan dengan berbelanja secara offline. Fenomena ini tidak terlepas dari dasar penerimaan pelanggan terhadap suatu sistem yang telah dijelaskan oleh Davis (1989) melalui teori Technology Acceptance Model (TAM). Teori Technology Acceptance Model (TAM) merupakan suatu teori tindakan yang beralasan pada satu asumsi bahwa reaksi dan persepsi seseorang terhadap sesuatu hal akan menentukan sikap dan perilaku orang tersebut dalam penerimaan teknologi (Davis, 1989). Teori ini memodelkan bagaimana pengguna menerima dan menggunakan teknologi tertentu (Dauda \& Lee, 2015). Lebih lanjut, persepsi kemudahan penggunaan dan persepsi manfaat yang dirasakan oleh pelanggan merupakan dua konstruk utama dalam memengaruhi penggunaan dan pengapdosian suatu teknologi (Davis, 1989).

Persepsi kemudahan penggunaan dalam penerimaan teknologi merupakan tingkatan kepercayaan seseorang bahwa tidak memerlukan usaha keras dalam menggunakan suatu sistem (Davis, 1989). Layanan yang ditawarkan sistem e-commerce untuk memberikan kemudahan bagi pelanggan ketika berbelanja online seperti lebih fleksibel, karena e-commerce dapat dilakukan kapan dan di mana saja selama terhubung akses internet. Selain kemudahan penggunaan, layanan e-commerce juga memberikan manfaat bagi pelanggan seperti lebih efektif, karena pelanggan tidak perlu datang ke tempat perbelanjaan secara langsung. Persepsi manfaat didefinisikan Adamson \& Shine (2003) sebagai tingkatan kepercayaan seseorang bahwa penggunaan suatu teknologi mampu meningkatkan kinerja mereka. Ketika pelanggan merasakan bahwa suatu layanan telah memberikan manfaat bagi kehidupannya, maka pelanggan akan menggunakan layanan tersebut secara positif (Lin, 2011). Dari fenomena tersebut, penelitian ini bertujuan untuk mengetahui pengaruh persepsi kemudahan (perceived ease of use) dan persepsi manfaat (perceived usefulness) pada penggunaan sistem (actual system use) aplikasi Tokopedia yang dimediasi oleh variabel kepercayaan (trust).

\section{KAJIAN PUSTAKA DAN PENGEMBANGAN HIPOTESIS}

\section{Technology Acceptance Model (TAM)}

Technology Acceptance Model (TAM) atau Model Penerimaan Teknologi merupakan suatu model yang dikembangkan untuk menganalisa faktor-faktor yang memengaruhi penerimaan suatu teknologi 
(Davis, 1989). Teori ini mengacu pada satu asumsi bahwa reaksi dan persepsi seseorang terhadap sesuatu akan menentukan sikap dan perilaku orang tersebut dalam penerimaan teknologi (Davis, 1989).

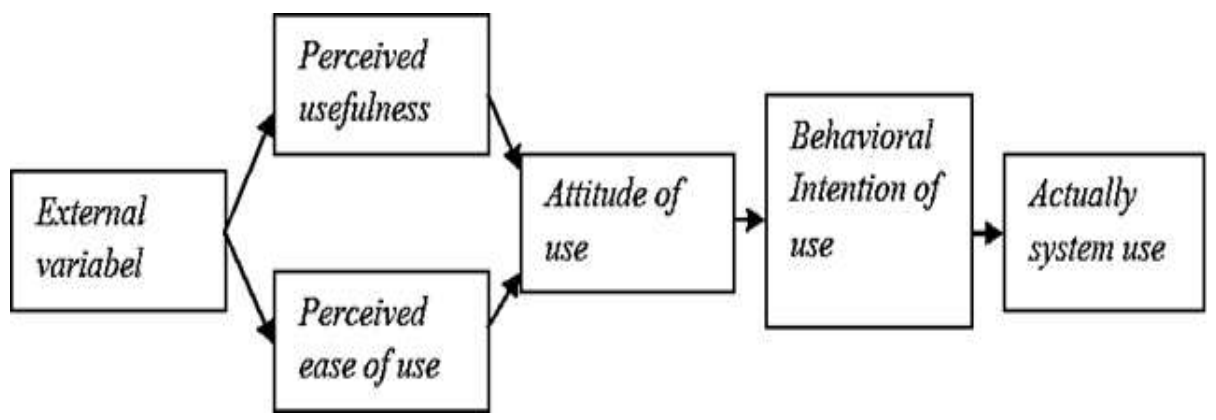

Sumber: Davis (1989)

\section{Gambar 1. MODEL TECHNOLOGY ACCEPTANCE MODEL (TAM)}

Menurut Davis (1989), di dalam teori Tehnology Acceptance Model (TAM) persepsi kemudahan penggunaan dan persepsi manfaat merupakan dua konstruk utama dalam memengaruhi segi pengadopsian suatu teknologi oleh pelanggan. Kedua variabel tersebut merupakan faktor dasar yang menjadi perhatian pengguna ketika memutuskan untuk menerima dan menggunakan suatu teknologi karena memiliki hubungan dalam prediksi sikap seseorang (Davis, 1989).

\section{Persepsi Kemudahan (Perceived Ease of Use)}

Menurut Davis (1989) persepsi kemudahan penggunaan didefinisikan sebagai ukuran kepercayaan seseorang bahwa suatu sistem teknologi dapat dengan mudah dipahami dan digunakan. Menurut Jogiyanto (2007:114) persepsi kemudahan merupakan sebuah ukuran dari sejauh mana seseorang percaya bahwa penggunaan teknologi akan bebas dari usaha baik waktu maupun tenaga. Jika suatu sistem dapat dengan mudah digunakan, sistem tersebut akan mendorong ketertarikan seseorang untuk memelajari fitur-fiturnya hingga berniat untuk terus menggunakannya (Hamid et al., 2016). Perusahaan yang menerapkan kemudahan didalam sistemnya hingga dapat menyederhanakan proses pemesanan akan mendorong pelanggan untuk melakukan pembelian secara online (Venkatesh \& Davis, 2000). Indikator yang digunakan untuk mengukur variabel persepsi kemudahan penggunaan pada penelitian ini mengadopsi penelitian Davis (1989) dalam Aziziyah (2021) yang meliputi: mudah dipahami, mudah digunakan, dan fleksibel.

\section{Persepsi Manfaat (Perceived Usefulness)}

Persepsi manfaat didefinisikan Adamson \& Shine (2003) sebagai suatu tingkatan kepercayaan seseorang bahwa penggunaan suatu teknologi mampu meningkatkan kinerja mereka. Davis (1989) mendefinisikan persepsi manfaat sebagai suatu tingkatan di mana seseorang percaya bahwa penggunaan suatu teknologi dapat meningkatkan prestasi kerja orang tersebut. Pelanggan yang memiliki persepsi manfaat yang tinggi akan termotivasi untuk menggunakan layanan. Ketika pelanggan merasakan bahwa suatu layanan dapat memberikan manfaat bagi kehidupannya, maka secara positif pelanggan akan menggunakan layanan tersebut (Lin, 2011). Pelanggan yang telah merasakan manfaat dari bagaimana sebuah sistem dapat meningkatkan produktifitas dan kinerjanya maka peluang pelanggan tersebut untuk memutuskan melakukan pembelian online semakin besar (Suberi \& Ab, 2014). Indikator yang digunakan untuk mengukur variabel persepsi manfaat pada penelitian ini mengadopsi penelitian Davis (1989) dalam Suhir (2014) yang meliputi: meningkatkan efektifitas, meningkatkan kinerja, dan meningkatkan produktifitas.

\section{Kepercayaan (Trust)}

Kepercayaan didefinisikan sebagai keyakinan dari apakah sebuah teknologi aman dan dapat dipercaya (Dahlberg et al., 2003). Minat pelanggan dalam membeli produk online dipengaruhi oleh kepercayaan mereka terhadap vendor online tersebut (Kim et al., 2008). Menurut Turban et al. (2010:187) 
Rizky Ramadhany Sito Putri \& Sri Setyo Iriani. Pengaruh Perceived Ease of Use dan Perceived Usefulness terhadap Keputusan Penggunaan Aplikasi Tokopedia melalui Trust sebagai Variabel Intervening

kepercayaan merupakan faktor penting dalam memengaruhi pengambilan keputusan pelanggan untuk mencapai kesepakatan antara konsumen dan penjual dalam bertransaksi online ketika tidak dapat bertemu secara langsung. Sehingga kehilangan kepercayaan merupakan salah satu alasan konsumen memutuskan tidak berbelanja melalui internet (Lee \& Turban, 2001). Indikator yang digunakan untuk mengukur variabel kepercayaan pada penelitian ini mengadopsi penelitian Mahkota et al. (2014) dan Lee \& Wan (2010) yang meliputi: percaya transaksi online, privasi terjaga, percaya online vendor, dan keamanan dalam bertransaksi.

\section{Penggunaan Sistem (Actual System Use)}

Menurut Davis (1989) penggunaan sistem didefinisikan sebagai kondisi ketika seseorang merasa senang dalam menggunakan suatu sistem jika dia merasa bahwa sistem tersebut tidak sulit ketika digunakan dan terbukti dapat meningkatkan produktivitas kinerja yang tercermin dari kondisi pada saat penggunaan. Menurut Jogiyanto (2007:114) penggunaan sistem merupakan tindakan yang dilakukan oleh seseorang dalam penggunaan sistem teknologi informasi dengan perilaku seseorang tersebut untuk penggunaan yang sesungguhnya (actual use). Indikator yang digunakan untuk mengukur variabel keputusan penggunaan sistem pada penelitian ini mengadopsi penelitian Davis (1989) dalam Aziziyah (2021) dan Andyka et al. (2012) yang meliputi: intensitas penggunaan dan frekuensi penggunaan.

\section{Hubungan antar Variabel}

Kepercayaan memainkan peran besar dalam layanan sistem e-commerce dibuktikan oleh Al-Sharafi (2017) di mana persepsi kemudahan penggunaan dapat memengaruhi kepercayaan pelanggan secara signifikan didalam layanan banking di negara Jordan sehingga meningkat dan menurunnya kepercayaan pelanggan terhadap suatu sistem secara langsung berpengaruh terhadap keputusan dalam berbelanja online.

H1: Terdapat pengaruh positif dan signifikan persepsi kemudahan terhadap kepercayaan.

Menurut Suberi \& Ab (2014) persepsi positif dari layanan berbelanja melalui internet yang dapat meningkatkan kinerja dinilai sangat penting dalam menentukan keputusan pelanggan. Ketika pelanggan merasakan percaya dalam sistem berbelanja online, maka mereka akan semakin terlibat dalam aktivitas belanja online. Menurut Lee \& Luo (2015) persepsi manfaat yang dirasakan pelanggan ketika menggunakan layanan mobile website memiliki pengaruh terhadap kepercayaan pelanggan secara signifikan.

H2: Terdapat pengaruh positif dan signifikan persepsi manfaat terhadap kepercayaan.

Menurut Dahlberg et al. (2003) kepercayaan merupakan suatu keyakinan dari aman dan dapat dipercaya atau tidaknya sebuah teknologi. Minat pelanggan dalam membeli produk online dipengaruhi oleh kepercayaan mereka terhadap vendor online tersebut (Kim et al., 2008). Menurut Al-Sharafi (2016) dan Corbitt et al. (2003) kepercayaan merupakan faktor penting bagi pelanggan ketika memutuskan untuk menggunakan dan menerima media transaksi online. Lebih lanjut, Mensah et al. (2017) dengan obyek penelitian e-government pada pelajar di Korea menunjukkan bahwa kepercayaan dapat memengaruhi para pelajar untuk menggunakan layanan tersebut.

H3: Terdapat pengaruh positif dan signifikan kepercayaan terhadap penggunaan sistem aplikasi Tokopedia.

Menurut Davis (1989) persepsi kemudahan penggunaan merupakan ukuran kepercayaan seseorang bahwa suatu sistem teknologi dapat dengan mudah dipahami dan digunakan. Pernyataan ini mendukung penelitian Iriani \& Andjarwati (2020) bahwa persepsi kemudahan penggunaan berpengaruh positif dan signifikan terhadap keputusan dalam berbelanja online. Menurut Arta \& Azizah (2020) desain fitur pada aplikasi Gojek yang mudah dipahami dan dipelajari secara signifikan memengaruhi penggunaan konsumen. Menurut Fatuh \& Widyastuti (2017) semakin mudah cara 
mengoperasikan aplikasi pada layanan Uber berpengaruh terhadap keputusan penggunaan layanannya. Lebih lanjut, Aziziyah (2021) menunjukkan adanya pengaruh positif persepsi kemudahan penggunaan terhadap penggunaan layanan aplikasi Traveloka secara langsung. Namun meski demikian, Agrebi \& Jallais (2015) menunjukkan persepsi kemudahan penggunaan tidak berpengaruh terhadap keputusan untuk menggunakan layanan smartphone di Prancis.

H4: Terdapat pengaruh positif dan signifikan persepsi kemudahan terhadap penggunaan sistem aplikasi Tokopedia.

Menurut Davis (1989) persepsi manfaat merupakan suatu tingkatan di mana seseorang percaya bahwa penggunaan suatu teknologi dapat meningkatkan prestasi kerja orang tersebut. Ketika pelanggan merasakan bahwa suatu layanan telah memberikan manfaat bagi kehidupannya, maka secara positif pelanggan akan menggunakan layanan tersebut (Lin, 2011). Menurut Arta \& Azizah (2020) terdapat pengaruh dari manfaat yang dirasakan pelanggan terhadap keputusan untuk menggunakan layanan Go-Food pada aplikasi Gojek. Menurut Iriani \& Andjarwati (2020) persepsi manfaat berpengaruh positif dan signifikan terhadap keputusan dalam berbelanja online. Namun meski demikian, menurut Budyastuti \& Iskandar (2018) persepsi manfaat tidak memengaruhi penggunaan layanan $e$-commerce oleh pelanggan.

H5: Terdapat pengaruh positif dan signifikan persepsi manfaat terhadap penggunaan sistem aplikasi Tokopedia.

H4

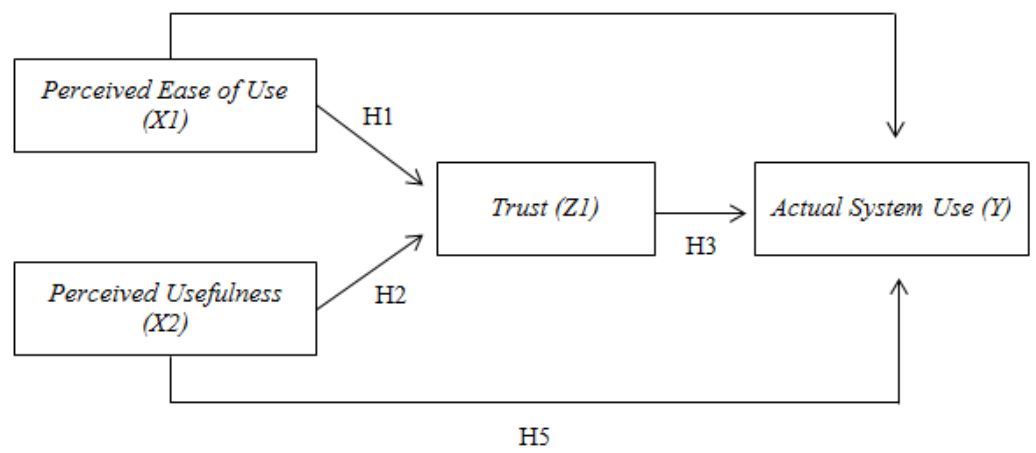

Sumber: Data diolah

Gambar 2. MODEL PENELITIAN

\section{METODE PENELITIAN}

Penelitian ini menggunakan pendekatan kuantitatif dengan jenis penelitian konklusif. Data penelitian yang digunakan adalah data primer yang diperoleh melalui hasil jawaban dari para responden atas kuesinoner yang diajukan, data sekunder yang diperoleh melalui studi pustaka literatur dan internet research yang digunakan untuk melengkapi data dari data primer dan data sekunder. Variabel bebas pada penelitian ini adalah persepsi kemudahan (perceived ease of use) dan persepsi manfaat (perceived usefulness), variabel mediasinya adalah kepercayaan (trust), sedangkan variabel terikatnya adalah penggunaan sistem (actual system use).

Populasi dalam penelitian ini adalah masyarakat yang pernah menggunakan aplikasi Tokopedia pada tahun 2020 dengan karakteristik responden adalah masyarakat millennial berusia 15-39 tahun dan pernah mengakses aplikasi tersebut melalui smartphone. Pemilihan populasi didasarkan pada tahun terjadinya fenomena di mana pengguna aplikasi Tokopedia mengalami penurunan ketika penggunaan e-commerce meningkat sedangkan pada pemilihan karakteristik umur didasarkan pada survei oleh Badan Pusat Statistik yang menyatakan bahwa pengguna e-commerce didominasi oleh generasi millennial (Bps.go.id, 2020). Sampel yang digunakan berjumlah 200 responden. Teknik pengumpulan 
Rizky Ramadhany Sito Putri \& Sri Setyo Iriani. Pengaruh Perceived Ease of Use dan Perceived Usefulness terhadap Keputusan Penggunaan Aplikasi Tokopedia melalui Trust sebagai Variabel Intervening

sampel menggunakan teknik non probability sampling dengan teknik judgemental sampling sesuai dengan karakteristik responden. Teknik pengumpulan data dilakukan dengan membagikan instrumen penelitian berupa kuesioner secara online melalui Google Form menggunakan media Whatsapp dan Instagram. Masing-masing item pernyataan dalam kuesioner diukur menggunakan teknik Skala Likert lima point. Instrumen penelitian tersebut kemudian diuji untuk mengetahui validitas dan reliabilitasnya terlebih dahulu. Selanjutnya data yang terkumpul dianalisis dan diolah dengan teknik Path Analysis menggunakan program AMOS versi 23.

\section{HASIL DAN PEMBAHASAN}

\section{Profil Responden}

Berdasarkan data yang berhasil terkumpul dari 200 responden yang telah berpartisipasi dalam penelitian ini, pada Tabel 1 diketahui bahwa responden dengan jenis kelamin laki-laki maupun perempuan memiliki jumlah yang tidak jauh berbeda. Perolehan responden berjenis kelamin laki-laki sebanyak 103 orang $(51,5 \%)$. Sedangkan responden dengan jenis kelamin perempuan sebanyak 97 orang $(48,5 \%)$. Bersadarkan karakteristik usia, mayoritas responden berusia 15-24 tahun dengan jumlah 173 orang (49\%). Berdasarkan karakteristik pekerjaan, responden didominasi oleh mahasiswa dengan jumlah 98 orang (49 \%) disusul dengan pegawai swasta dengan jumlah 45 orang $(22,5 \%)$. Rata-rata penghasilan responden terbanyak berada pada rentang <Rp1.500.000 dengan jumlah 93 orang (46,5\%) dan Rp1.500.000-Rp3.000.000 dengan jumlah 45 orang $(22,5 \%)$.

Tabel 1.

\section{FREKUENSI PROFIL RESPONDEN}

\begin{tabular}{llcc}
\hline & Karakteristik Responden & Frekuensi & Presentase (\%) \\
\hline Jenis Kelamin & Laki-Laki & 103 & $51,5 \%$ \\
Usia & Perempuan & 97 & $48,5 \%$ \\
\multirow{3}{*}{ Pekerjaan } & $15-24$ tahun & 173 & $86,5 \%$ \\
& $25-39$ tahun & 27 & $13,5 \%$ \\
& Pelajar & 1 & $0,5 \%$ \\
& Mahasiswa & 98 & $49 \%$ \\
& Swasta & 45 & $22,5 \%$ \\
& Pegawai Negeri & 10 & $5 \%$ \\
Pendapatan Bulanan & Wiraswasta & 21 & $10,5 \%$ \\
& Lainnya & 25 & $12,5 \%$ \\
& $<$ Rp1.500.000 & 93 & $46,5 \%$ \\
& Rp1.500.000 - Rp3.000.000 & 45 & $22,5 \%$ \\
& Rp3.000.000 - Rp4.500.000 & 17 & $8,5 \%$ \\
& Rp4.500.000 - Rp6.000.000 & 31 & $15,5 \%$ \\
& $>$ Rp6.000.000 & 14 & $7 \%$ \\
\hline
\end{tabular}

Sumber: Data diolah

\section{Uji Validitas dan Reliabilitas}

Sebelum data penelitian dianalisis, terlebih dahulu dilakukan uji validitas dan reliabilitasnya. Uji validitas dan reliabilitas dilakukan dengan membagikan kuesioner kepada 200 responden secara online. Item pernyataan dapat dikatakan valid apabila memiliki nilai correlated item total lebih dari 0,3 dan reliabel apabila memiliki nilai cronbach alpha lebih dari 0,7. Berdasarkan hasil analisa uji validitas menunjukkan bahwa seluruh item dalam kuesioner penelitian terbukti valid karena memiliki nilai r-hitung lebih dari 0,3. Berdasarkan Tabel 2, hasil uji reliabilitas menunjukkan bahwa seluruh variabel didalam penelitian ini memiliki nilai cronbach alpha lebih dari 0,7 sehingga item pernyataan pada keseluruhan variabel dinyatakan valid dan reliabel untuk digunakan sebagai alat dalam menguji 
pengaruh persepsi kemudahan penggunaan dan persepsi manfaat terhadap penggunaan sistem melalui variabel kepercayaan.

Tabel 2.

HASIL UJI VALIDITAS DAN RELIABILITAS

\begin{tabular}{|c|c|c|c|}
\hline No. & Pernyataan & $\begin{array}{c}\text { Correlated Item } \\
\text { Total }\end{array}$ & $\begin{array}{l}\text { Cronbach's } \\
\text { Alpha }\end{array}$ \\
\hline \multicolumn{4}{|c|}{ Perceived Ease of Use } \\
\hline 1. & Aplikasi Tokopedia menggunakan bahasa yang mudah dimengerti & 0,531 & 0,825 \\
\hline & Aplikasi Tokopedia memiliki tampilan menu yang mudah dipahami & 0,549 & \\
\hline & $\begin{array}{l}\text { Aplikasi Tokopedia menyediakan keterangan lengkap terkait cara } \\
\text { penggunaan aplikasi }\end{array}$ & 0,471 & \\
\hline 4. & $\begin{array}{l}\text { Aplikasi Tokopedia menyediakan kemudahan dalam proses } \\
\text { pencarian produk }\end{array}$ & 0,622 & \\
\hline 5. & $\begin{array}{l}\text { Aplikasi Tokopedia menyediakan kemudahan dalam proses } \\
\text { pembayaran }\end{array}$ & 0,559 & \\
\hline 6. & Aplikasi Tokopedia dapat digunakan untuk berbelanja kapan saja & 0,589 & \\
\hline 7. & Aplikasi Tokopedia dapat digunakan dimana saja & 0,502 & \\
\hline & $\begin{array}{l}\text { Aplikasi Tokopedia dapat diakses dengan media apa saja yang } \\
\text { terhubung internet }\end{array}$ & 0,552 & \\
\hline \multicolumn{4}{|c|}{ Perceived Usefulness } \\
\hline 9. & Aplikasi Tokopedia menghemat waktu saya dalam berbelanja & 0,598 & 0,817 \\
\hline 10. & $\begin{array}{l}\text { Aplikasi Tokopedia membuat saya tidak perlu datang ke mall/toko } \\
\text { secara langsung }\end{array}$ & 0,550 & \\
\hline 11. & $\begin{array}{l}\text { Mencari kebutuhan dari berbagai daerah dalam aplikasi Tokopedia } \\
\text { dapat dilakukan dengan cepat }\end{array}$ & 0,610 & \\
\hline & $\begin{array}{l}\text { Proses berbelanja dengan aplikasi Tokopedia dapat dilakukan } \\
\text { dengan cepat }\end{array}$ & 0,639 & \\
\hline 13 & $\begin{array}{l}\text { Aplikasi Tokopedia membuat saya dapat berbelanja online dengan } \\
\text { melakukan aktivitas lain }\end{array}$ & 0,640 & \\
\hline \multicolumn{4}{|c|}{ Trust } \\
\hline & $\begin{array}{l}\text { Saya percaya aplikasi Tokopedia dapat memberikan pelayanan } \\
\text { terbaik untuk berbelanja online }\end{array}$ & 0,506 & 0,898 \\
\hline & $\begin{array}{l}\text { Saya percaya aplikasi Tokopedia menyediakan produk yang } \\
\text { berkualitas }\end{array}$ & 0,696 & \\
\hline & $\begin{array}{l}\text { Saya percaya aplikasi Tokopedia dapat menjaga data pribadi } \\
\text { pengguna }\end{array}$ & 0,723 & \\
\hline & $\begin{array}{l}\text { Saya percaya aplikasi Tokopedia dapat menghargai kerahasiaan data } \\
\text { pengguna }\end{array}$ & 0,722 & \\
\hline & $\begin{array}{l}\text { Saya percaya aplikasi Tokopedia menerima jika pengguna } \\
\text { mengajukan complain }\end{array}$ & 0,700 & \\
\hline & $\begin{array}{l}\text { Saya percaya aplikasi Tokopedia menerima jika pengguna } \\
\text { mengajukan penukaran produk }\end{array}$ & 0,728 & \\
\hline & Saya percaya berbelanja online dengan aplikasi Tokopedia aman & 0,677 & \\
\hline & $\begin{array}{l}\text { Saya percaya aplikasi Tokopedia tidak akan mengambil keuntungan } \\
\text { illegal dari pengguna }\end{array}$ & 0,708 & \\
\hline \multicolumn{4}{|c|}{ Actual System Use } \\
\hline & $\begin{array}{l}\text { Saya memilih menggunakan aplikasi Tokopedia saat membutuhkan } \\
\text { produk yang lokasi tokonya jauh }\end{array}$ & 0,535 & 0,710 \\
\hline 23. & $\begin{array}{l}\text { Saya memilih menggunakan aplikasi Tokopedia saat membutuhkan } \\
\text { produk yang susah dicari }\end{array}$ & 0,576 & \\
\hline 24. & $\begin{array}{l}\text { Saya sering berbelanja online dengan aplikasi Tokopedia dibanding } \\
\text { berbelanja ke mall/toko secara langsung }\end{array}$ & 0,453 & \\
\hline
\end{tabular}

Sumber: Data diolah 
Rizky Ramadhany Sito Putri \& Sri Setyo Iriani. Pengaruh Perceived Ease of Use dan Perceived Usefulness terhadap Keputusan Penggunaan Aplikasi Tokopedia melalui Trust sebagai Variabel Intervening

\section{Uji Asumsi Analisis Jalur}

Data yang telah terkumpul kemudian dianalisis menggunakan analisis jalur untuk memastikan bahwa variabel telah berdistribusi normal dan tidak mengandung outlier untuk menghindari adanya bias didalam analisis data. Uji normalitas dilakukan dengan melihat apakah data memiliki c.r (critical ratio) berada di antara rentang nilai -2,58 sampai 2,58. Hasil pada uji normalitas menunjukkan bahwa nilai critical ratio skewness value setiap variabel yakni nilai persepsi kemudahan penggunaan sebesar $-2,200$, persepsi manfaat sebesar -2,003, kepercayaan pelanggan sebesar 0,476 dan penggunaan sistem sebesar -2,153. Hasil pada uji normalitas dilihat dari nilai critical ratio multivariate menunjukkan nilai sebesar $-1,142$. Sehingga dapat diasumsikan bahwa data telah berdistribusi normal dan dapat digunakan untuk uji selanjutnya. Hasil pada uji outlier menunjukkan bahwa data telah memenuhi uji asumsi outlier dikarenakan nilai mahalonobis $d$-squared tidak ada yang lebih besar dari nilai critical value of chi square 0,001 dengan $\mathrm{dF}$ sebesar 4 yaitu $\mathrm{x}^{2}=18,476$. Sedangkan pada hasil uji asumsi multikolinieritas yang dilakukan untuk mendeteksi apakah terdapat hubungan linier di antara masingmasing variabel menunjukkan nilai determinasi matriks kovarians jauh dari nol yaitu sebesar 1597,368. Sehingga dapat diasumsikan bahwa tidak terdapat indikasi adanya multikolinieritas dalam data. Kemudian pada hasil uji linieritas menunjukkan bahwa data telah memenuhi hubungan dari seluruh variabel karena nilai signifikansi dari keseluruhan variabel telah kurang dari 0,05.

\section{Uji Analisis Path}

Hasil nilai pada standarized regression weights menunjukkan bahwa variabel persepsi kemudahan penggunaan memiliki perubahan positif pada variabel kepercayaan dengan nilai koefisien jalur sebesar 0,354 dan pada variabel penggunaan sistem sebesar 0,352. Nilai ini menunjukkan bahwa semakin mudah penggunaan sistem aplikasi Tokopedia akan semakin mendorong pelanggan untuk percaya dan menggunakan aplikasi Tokopedia. Pada variabel persepsi manfaat diketahui memiliki perubahan positif pada variabel kepercayaan dengan nilai koesfisien jalur sebesar 0,268 dan pada variabel penggunaan sistem sebesar 0,102. Nilai ini menunjukkan bahwa semakin besar sistem aplikasi Tokopedia dapat memberikan manfaat pada pelanggan akan semakin mendorong pelanggan untuk percaya dan menggunakan aplikasi Tokopedia. Kemudian pada variabel kepercayaan diketahui memiliki nilai koefisien jalur sebesar 0,345 pada variabel penggunaan sistem yang artinya semakin percaya pelanggan maka penggunaan aplikasi Tokopedia oleh pelanggan juga akan meningkat. Model diagram jalur pada penelitian ini ditunjukkan oleh gambar 3 yang telah dikonversikan ke dalam persamaan model struktural (1) dan (2).

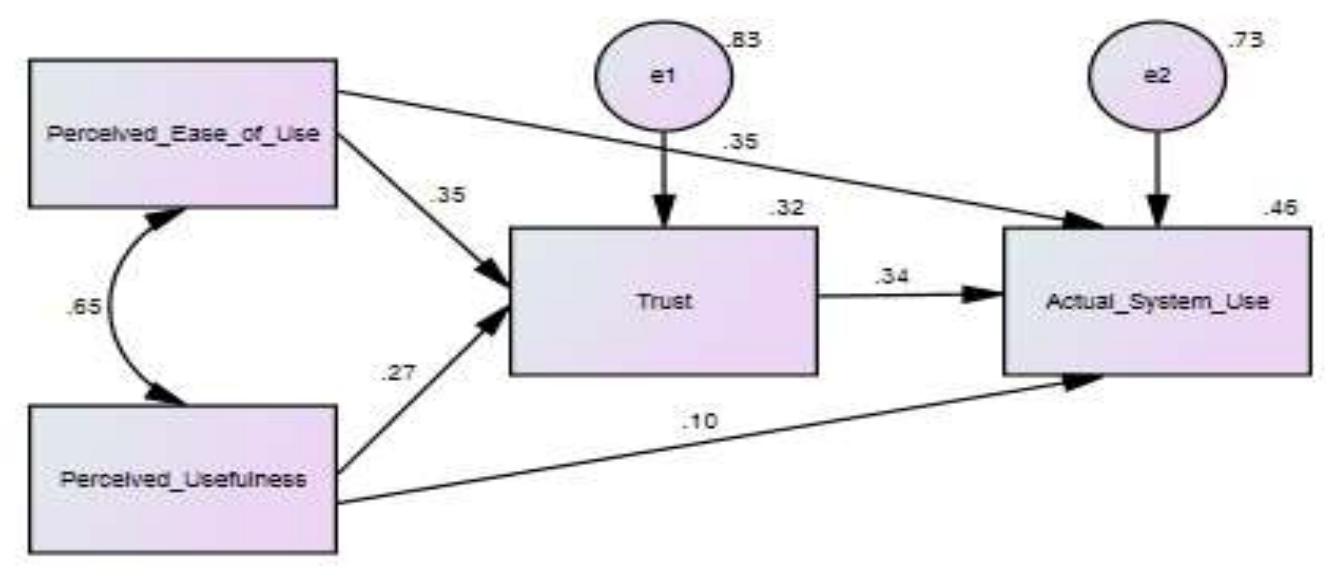

Sumber: Data AMOS

Gambar 3. DIAGRAM JALUR

$\mathrm{Z}=\mathrm{b}_{1} \mathrm{X}_{1}+\mathrm{b}_{2} \mathrm{X}_{2}+\mathrm{e}_{1}=0,35 \mathrm{X}_{1}+0,27 \mathrm{X}_{2}+0,83$

$\mathrm{Y}=\mathrm{b}_{4} \mathrm{X}_{1}+\mathrm{b}_{5} \mathrm{X}_{2}+\mathrm{b}_{3} \mathrm{Z}+\mathrm{e}_{2}=0,35 \mathrm{X}+0,10 \mathrm{X}+0,34 \mathrm{X}+0,73$ 


\section{Uji Kelayakan Model}

Pengujian dalam kelayanan model dilakukan dengan melihat koefisien determinasi total (total $R^{2}$ ) dengan formula (1) dengan batasan $\mathrm{R}_{1}{ }^{2}, \mathrm{R}_{2}{ }^{2}$ adalah $r$-square dari dua variabel terikat yaitu persepsi kemudahan penggunaan dan persepsi manfaat.

$$
\begin{aligned}
R^{2} \text { total } & =1-\left(1-\mathrm{R}_{1}{ }^{2}\right)\left(1-\mathrm{R}_{2}{ }^{2}\right) \\
& =1-(1-0,320)(1-0,462) \\
& =1-(0,680)(0,538) \\
& =1-0,366 \\
& =0,634=63,4 \% \\
R^{2} \text { total } & =0,634 \text { atau } 63,4 \% \ldots \ldots . . . . . .
\end{aligned}
$$

Dari hasil nilai koefisien determinasi total $\left(\right.$ total $\left.R^{2}\right)$ menunjukkan bahwa kontribusi model untuk menjelaskan hubungan struktural dari keempat variabel dalam penelitian ini adalah sebesar $63,4 \%$. Sehingga model dapat dinyatakan telah layak untuk diteliti. Sedangkan pada sisa hubungan sebesar $36,6 \%$ dapat dijelaskan melalui variabel lain atau melalui variabel error.

\section{Uji Hipotesis}

Uji hipotesis dapat dilakukan dengan membandingkan nilai probabilitas (P) dengan taraf signifikansi (a) yaitu sebesar 0,05 . Apabila suatu hipotesis memiliki nilai probabilitas yang kurang atau sama dengan taraf signifikansi, maka hipotesis dapat diterima dan begitu pula sebaliknya. Dapat diterima maupun ditolaknya sebuah hipotesis juga dapat dilakukan dengan membandingkan nilai c.r (critical ratio) hitung dengan c.r (critical ratio) standart pada taraf signifikansi sebesar 0,05 yaitu 2,00. Artinya, hubungan variabel dikatakan signifikan dan terdapat pengaruh antara variabel bebas terhadap variabel terikat apabila c.r (critical ratio) hitung memiliki nilai $\geq 2,00$. Berdasarkan Tabel 3, diperoleh hasil bahwa H1, H2, H3 dan $\mathrm{H} 4$ diterima karena memiliki nilai c.r (critical ratio) hitung $\geq 2,00$ dan nilai signifikansi $(\mathrm{P}) \leq 0,05$. Sedangkan $\mathrm{H} 5$ memiliki nilai c.r (critical ratio) hitung $<2,00$ dan nilai signifikansinya $(\mathrm{P})>0,05$ sehingga hipotesis ditolak.

\section{Tabel 3.}

\section{HASIL UJI HIPOTESIS}

\begin{tabular}{lllcc}
\hline \multicolumn{1}{c}{ Hipotesis } & & Hipotesis Jalur & C.R & P \\
\hline H1 (Diterima) & Trust & $\leftarrow$ Perceived Ease of Use & 4,621 & $* * *$ \\
H2 (Diterima) & Trust & $\leftarrow$ Perceived Usefulness & 3,502 & $* * *$ \\
H3 (Diterima) & Actual System Use & $\leftarrow$ Trust & 5,465 & $* * *$ \\
H4 (Diterima) & Actual System Use & $\leftarrow$ Perceived Ease of Use & 4,907 & $* * *$ \\
H5 (Ditolak) & Actual System Use & $\leftarrow$ Perceived Usefulness & 1,455 & 0,146 \\
\hline
\end{tabular}

Sumber: Output AMOS 23, data diolah

Hasil pada uji hipotesis 1 (H1) hubungan persepsi kemudahan penggunaan terhadap variabel kepercayaan menunjukkan hasil nilai CR hitung sebesar 4,621 $\geq 2,00$ dan nilai probabilitas sebesar $0,000$ ( $\mathrm{p} \leq 0,05)$. Hasil ini menunjukkan bahwa hipotesis 1 (H1) diterima, yang artinya bahwa semakin mudah penggunaan aplikasi Tokopedia terbukti secara positif dan signifikan dapat memengaruhi tingginya kepercayaan pelanggan pada aplikasi tersebut.

Hasil pada uji hipotesis 2 (H2) hubungan persepsi manfaat terhadap variabel kepercayaan menunjukkan hasil nilai CR hitung sebesar 3,502 $\geq 2,00$ dan nilai probabilitas sebesar $0,000(\mathrm{p} \leq$ 0,05). Hasil ini menunjukkan bahwa hipotesis 2 (H2) diterima, yang artinya bahwa semakin bermanfaat aplikasi Tokopedia terbukti secara positif dan signifikan dapat memengaruhi tingginya kepercayaan pelanggan pada aplikasi tersebut. 
Rizky Ramadhany Sito Putri \& Sri Setyo Iriani. Pengaruh Perceived Ease of Use dan Perceived Usefulness terhadap Keputusan Penggunaan Aplikasi Tokopedia melalui Trust sebagai Variabel Intervening

Hasil pada uji hipotesis 3 (H3) hubungan kepercayaan terhadap variabel penggunaan sistem menunjukkan hasil nilai $\mathrm{CR}$ hitung sebesar $5,465 \geq 2,00$ dan nilai probabilitas sebesar $0,000(\mathrm{p} \leq$ 0,05). Hasil ini menunjukkan bahwa hipotesis $3(\mathrm{H} 3)$ diterima, yang artinya bahwa semakin tinggi rasa percaya pelanggan terhadap aplikasi Tokopedia terbukti secara positif dan signifikan dapat memengaruhi keputusan pelanggan untuk menggunakan sistem aplikasi tersebut.

Hasil pada uji hipotesis 4 (H4) hubungan persepsi kemudahan penggunaan terhadap variabel penggunaan sistem menunjukkan hasil nilai CR hitung sebesar 4,907 $\geq 2,00$ dan nilai probabilitas sebesar $0,000(\mathrm{p} \leq 0,05)$. Hasil ini menunjukkan bahwa hipotesis $4(\mathrm{H} 4)$ diterima, yang artinya bahwa semakin tinggi kemudahan penggunaan aplikasi Tokopedia yang dapat dirasakan pelanggan terbukti secara positif dan signifikan dapat memengaruhi keputusan pelanggan untuk menggunakan sistem aplikasi tersebut.

Hasil pada uji hipotesis 5 (H5) hubungan persepsi manfaat terhadap variabel penggunaan sistem menunjukkan nilai CR hitung sebesar $1,455<2,00$ dan nilai probabilitas sebesar 0,146 ( $\mathrm{p} \geq 0,05)$. Hasil ini menunjukkan bahwa hipotesis 5 (H5) ditolak, yang artinya bahwa semakin tinggi manfaat yang dapat dirasakan pelanggan pada sistem aplikasi Tokopedia terbukti tidak dapat memengaruhi keputusan pelanggan untuk menggunakan sistem aplikasi tersebut.

Menguji pengaruh tidak langsung variabel bebas $(\mathrm{X})$ terhadap variabel terikat $(\mathrm{Y})$ melalui variabel mediasi (Z) dilakukan uji mediasi dengan menggunakan Sobel Test. Variabel dikatakan dapat memediasi apabila nilai probabilitas signifikansinya sebesar $0,0001(\mathrm{P} \leq 0,05)$. Berdasarkan hasil pada uji sobel test, variabel kepercayaan memiliki nilai sobel $0,00(\mathrm{P} \leq 0,05)$. Artinya, variabel kepercayaan terbukti dapat memediasi hubungan antara persepsi kemudahan penggunaan persepsi manfaat terhadap penggunaan sistem aplikasi Tokopedia. Semakin baik hubungan persepsi kemudahan penggunaan dan persepsi manfaat pada kepercayaan yang dirasakan pelanggan, maka akan semakin besar pula kemungkinan bahwa pelanggan akan memutuskan untuk menggunakan aplikasi Tokopedia dalam berbelanja online.

\section{Pengaruh Perceived Ease of Use terhadap Trust}

Penelitian ini menunjukkan terdapat pengaruh yang positif dan signifikan dari persepsi kemudahan penggunaan terhadap kepercayaan, yang artinya bahwa semakin mudah penggunaan aplikasi Tokopedia maka kepercayaan pelanggan pada aplikasi tersebut juga semakin meningkat. Berdasarkan hasil jawaban responden, indikator percaya transaksi online dengan item pernyataan "Saya percaya aplikasi Tokopedia dapat memberikan pelayanan terbaik untuk berbelanja online" memiliki nilai ratarata jawaban tertinggi pada variabel kepercayaan. Ketika pelanggan merasakan kemudahan dalam penggunaan sistem e-commerce, kepercayaan pelanggan untuk berbelanja secara online juga akan meningkat karena pelanggan percaya aplikasi Tokopedia dapat memberikan pelayanan yang terbaik bagi mereka. Hasil ini mendukung penelitian terdahulu oleh Al-Sharafi (2017) bahwa persepsi kemudahan penggunaan memengaruhi kepercayaan terhadap layanan online secara signifikan.

\section{Pengaruh Perceived Usefulness terhadap Trust}

Penelitian ini menunjukkan terdapat pengaruh yang positif dan signifikan dari persepsi manfaat terhadap kepercayaan pelanggan, yang artinya bahwa semakin bermanfaat aplikasi Tokopedia maka kepercayaan pelanggan pada aplikasi tersebut juga semakin meningkat.Berdasarkan hasil jawaban responden diketahui pernyataan item dengan nilai tertinggi dalam mengukur persepsi manfaat adalah "Aplikasi Tokopedia dapat membuat saya dapat berbelanja online dengan melakukan aktivitas lain". Ketika sedang beraktivitas dan pelanggan perlu untuk melakukan pemenuhan kebutuhan secara online, pelanggan dapat memercayakan aktivitas tersebut dengan menggunakan aplikasi Tokopedia. Sehingga dalam aktivitas apapun yang sedang pelanggan kerjakan, pelanggan tetap dapat merasakan manfaat berbelanja dengan nyaman. Hasil ini mendukung penelitian terdahulu oleh Lee \& Luo (2015) bahwa persepsi manfaat dari layanan mobile website memiliki pengaruh yang signifikan terhadap kepercayaan pelanggan. 


\section{Pengaruh Trust terhadap Penggunaan Sistem}

Kepercayaan pelanggan memiliki pengaruh yang positif dan signifikan terhadap penggunaan system. Artinya semakin tinggi rasa percaya pelanggan terhadap aplikasi Tokopedia maka akan semakin memengaruhi keputusan pelanggan untuk menggunakan sistem aplikasi tersebut. Berdasarkan hasil jawaban responden diketahui bahwa pernyataan item dengan nilai tertinggi dalam mengukur variabel kepercayaan adalah "Saya percaya aplikasi Tokopedia dapat memberikan pelayanan terbaik untuk berbelanja online". Ketika pelanggan sedang membutuhkan suatu produk, pelanggan akan melakukan beberapa evaluasi untuk memutuskan bagaimana mereka memenuhi kebutuhan tersebut. Ketika pelanggan percaya bahwa aplikasi Tokopedia mampu memberikan pelayanan terbaik bagi mereka untuk berbelanja secara online terbukti dapat mendorong pelanggan untuk memilih menggunakannya. Pernyataan ini sesuai dengan Turban et al. (2010:187) bahwa mencapai kesepakatan antara konsumen dan penjual dalam bertransaksi online yang tidak dapat bertemu secara langsung, kepercayaan merupakan faktor penting dalam memengaruhi pengambilan keputusan pelanggan. Hasil ini mendukung penelitian terdahulu oleh Suberi \& Ab (2014) bahwa persepsi positif dari layanan berbelanja melalui internet yang dapat meningkatkan kinerja dinilai sangat penting dalam menentukan keputusan pelanggan. Semakin percaya pelanggan dalam berbelanja online, maka mereka akan semakin terlibat dalam aktivitas belanja online. Lebih lanjut, hasil ini juga mendukung penelitian terdahulu oleh Al-Sharafi (2016) dan Corbitt et al. (2003) di mana kepercayaan merupakan faktor yang penting untuk menggunakan dan menerima media transaksi online.

\section{Pengaruh Perceived Ease of Use terhadap Penggunaan Sistem}

Terdapat pengaruh positif dan signifikan dari persepsi kemudahan penggunaan terhadap penggunaan system. Semakin tinggi kemudahan penggunaan aplikasi Tokopedia yang dapat dirasakan pelanggan maka akan semakin memengaruhi keputusan pelanggan untuk menggunakan sistem aplikasi tersebut. Berdasarkan hasil jawaban responden, indikator fleksibel dengan item pernyataan "Aplikasi Tokopedia dapat digunakan untuk berbelanja kapan saja" dan "Aplikasi Tokopedia dapat digunakan dimana saja" memiliki nilai rata-rata jawaban tertinggi. Kemudahan berbelanja online menggunakan sistem dalam e-commerce dengan tidak terbatasinya waktu dan tempat untuk mengaksesnya terbukti dapat meningkatkan penggunaannya. Pelanggan dapat merasakan kemudahan berbelanja dari rumah dengan tidak perlu datang ke tempat perbelanjaan secara langsung. Pelanggan juga dapat berbelanja 24 jam tanpa dibatasi oleh waktu. Pernyataan ini sesuai dengan teori Technology Acceptance Model (TAM) yang didefinisikan Jogiyanto (2007:114) bahwa persepsi kemudahan penggunaan merupakan sebuah ukuran dari sejauh mana seseorang percaya bahwa penggunaan teknologi akan bebas dari usaha baik waktu maupun tenaga. Hasil ini sesuai dengan penelitian terdahulu oleh Hamid et al. (2016) bahwa jika suatu sistem dapat dengan mudah digunakan, sistem tersebut akan mendorong ketertarikan seseorang untuk memelajari fitur-fiturnya hingga berniat untuk terus menggunakannya. Hasil ini juga mendukung Iriani \& Andjarwati (2020), Arta \& Azizah (2020), Fatuh \& Widyastuti (2017) yang menunjukkan adanya pengaruh positif dan signifikan persepsi kemudahan terhadap penggunaan sistem e-commerce. Namun, hasil ini tidak mendukung Agrebi \& Jallais (2015) yang menunjukkan tidak adanya pengaruh persepsi kemudahan terhadap keputusan menggunakan system.

\section{Pengaruh Perceived Usefulness terhadap Penggunaan Sistem}

Persepsi manfaat tidak berpengaruh terhadap penggunaan system. Semakin tinggi manfaat yang dapat dirasakan pelanggan pada sistem aplikasi Tokopedia terbukti tidak dapat memengaruhi keputusan pelanggan untuk menggunakan sistem aplikasi tersebut. Pernyataan ini tidak mendukung teori Technology Acceptance Model (TAM) yang dijelaskan Davis (1989) bahwa persepsi manfaat merupakan salah satu konstruk utama dalam memengaruhi segi pengadopsian suatu teknologi oleh pelanggan. Berdasarkan hasil jawaban responden, kelima item dalam mengukur variabel persepsi manfaat memiliki nilai rata-rata yang cukup tinggi seperti "Aplikasi Tokopedia dapat membuat saya dapat berbelanja online dengan melakukan aktivitas lain" dan"Aplikasi Tokopedia membuat saya tidak perlu datang ke mall/toko secara langsung”. Meski pelanggan memiliki kesadaran atas manfaat yang dapat mereka terima ketika berbelanja online menggunakan aplikasi Tokopedia, hal tersebut tidak dapat tidak mendorong pelanggan untuk memutuskan menggunakan aplikasi tersebut. Keputusan ini dapat diakibatkan oleh terjadinya fenomena di mana diberitakan bahwa aplikasi 
Rizky Ramadhany Sito Putri \& Sri Setyo Iriani. Pengaruh Perceived Ease of Use dan Perceived Usefulness terhadap Keputusan Penggunaan Aplikasi Tokopedia melalui Trust sebagai Variabel Intervening

Tokopedia mengalami kebocoran data pengguna pada awal tahun 2020, sehingga informasi tersebut dapat menjadi pemicu kekhawatiran pelanggan hingga membatasi penggunaannya. Hasil ini mendukung penelitian terdahulu oleh Budyastuti \& Iskandar (2018) bahwa persepsi manfaat tidak berpengaruh dalam penggunaan layanan e-commerce oleh pelanggan. Hasil ini kemudian tidak selaras dengan penelitian Lin (2011) di mana ketika pelanggan merasakan suatu layanan telah memberikan manfaat bagi kehidupannya, maka secara positif pelanggan akan menggunakan layanan tersebut. Hasil ini juga tidak mendukung penelitian terdahulu oleh Arta \& Azizah (2020) dan Iriani \& Andjarwati (2020) bahwa persepsi manfaat berpengaruh positif dan signifikan terhadap penggunaan sistem layanan online. Namun pada penelitian ini ditemukan juga adanya pengaruh tidak langsung yang dapat dimediasi oleh variabel kepercayaan, yang artinya semakin baik persepsi manfaat pada kepercayaan yang pelanggan rasakan, akan berpengaruh terhadap keputusan penggunaan aplikasi Tokopedia.

\section{KESIMPULAN}

Berdasarkan hasil penelitian dan pembahasan yang telah dilakukan dapat disimpulkan bahwa persepsi kemudahan dan persepsi manfaat berpengaruh positif dan signifikan terhadap kepercayaan pelanggan, kepercayaan pelanggan dan kemudahan penggunaan berpengaruh positif dan signifikan terhadap pengunaan sistem, namun persepsi manfaat tidak berpengaruh terhadap penggunaan sistem dan kepercayaan pelanggan terbukti secara tidak langsung dapat memediasi hubungan persepsi kemudahan penggunaan dan persepsi manfaat terhadap penggunaan sistem.

Implikasi yang dapat digunakan melalui penelitian ini untuk perusahaan e-commerce maupun sistem online adalah berdasarkan karakteristik usia dan pekerjaan, pengguna didominasi oleh mahasiswa dan pegawai swasta dengan usia 15-24 tahun. Adapun kebutuhan yang paling banyak dicari ketika menggunakan sistem layanan belanja online antara lain pada responden laki-laki berusia 15-24 tahun adalah produk fashion dan barang elektronik, sedangkan pada responden laki-laki berusia 25-39 tahun adalah produk perlengkapan rumah tangga, barang elektronik dan pembayaran kebutuhan sehari-hari seperti listrik dan pulsa. Adapun pada responden perempuan berusia 15-24 tahun adalah produk fashion dan kecantikan, sedangkan pada responden perempuan berusia 25-39 tahun adalah produk perlengkapan rumah tangga, fashion, kecantikan, makanan dan minuman.

Implikasi manajerial, bagi aplikasi Tokopedia diharapkan dapat meningkatkan dan membangun kembali kepercayaan dari pelanggan dengan meningkatkan keamanan sistemnya dalam melindungi privasi pengguna dikarenakan dari fenomena yang terjadi di mana aplikasi Tokopedia pengalami penurunan pengguna disaat terjadi peningkatan akan penggunaan sistem e-commerce kemudian selaras dengan ditemukannya hasil dari tidak berpengaruhnya persepsi manfaat terhadap penggunaan sistem aplikasi Tokopedia. Sehingga meski pelanggan menyadari manfaat yang dapat mereka peroleh dari berbelanja online dengan aplikasi Tokopedia, tidak membuat pelanggan membuat keputusan untuk menggunakan sistem tersebut, namun terbukti dapat memengaruhi secara tidak langsung ketika dimediasi dengan variabel kepercayaan.

Penelitian ini tidak terlepas dari beberapa keterbatasan dan hambatan seperti pada penyebaran angket menggunakan item pernyataan tertutup sehingga pendapat responden mengenai aplikasi Tokopedia kurang dapat diekplorasi lebih dalam dan mayoritas responden berada pada satu daerah tertentu. Bagi penelitian selanjutnya, penyebaran kuesioner lebih merata dan menambahkan pertanyaan terbuka sehingga jawaban beragam dari responden dapat menjadi tambahan dalam pembahasan. Penelitian selanjutnya dapat menambahkan variabel yang memengaruhi penggunaan sistem $e$-commerce maupun layanan berbasis online lainnya seperti service quality, promotion, price maupun discount.

\section{DAFTAR PUSTAKA}

Adamson, I., \& Shine, J. 2003. Extending the New Technology Acceptance Model to Measure the User Information Systems Satisfaction in a Mandatory Environment: A Bank's Treasury. 
Technology Analysis \& Strategic Management. Vol. 15, No. 4, H. 441-455.

Agrebi, S., \& Jallais, J. (2015). Explain the Intention to Use Smartphones for Mobile Shopping. Journal of Retailing and Consumer Services, 22, 16-23. https://doi.org/10.1016/j.jretconser.2014.09.003

Al-Sharafi, M. A., Arshah, R. A., Abo-Shanab, E. A., \& Elayah, N. (2016). The Effect of Security and Privacy Perceptions on Customers' Trust to Accept Internet Banking Services: An extension of TAM. Journal of Engineering and Applied sciences, 11(3), 545-552.

Andyka, R. S., Endang Siti, A., \& Heru, S. (2012). Pengaruh Persepsi Kemudahan dan Persepsi Kemanfaatan Terhadap Penggunaan Youtube dengan Pendekatan TAM. Jurnal Administrasi Bisnis Universitas Brawijaya. 3 (1): 1-11

Arta, T. L. F., \& Azizah, S. N. (2020). Pengaruh Perceived Usefulness, Perceived Ease Of Use dan EService Quality Terhadap Keputusan Menggunakan Fitur Go-Food dalam Aplikasi Gojek. Jurnal Ilmiah Mahasiswa Manajemen, Bisnis Dan Akuntansi (JIMMBA), 2(2), 291-303. https://doi.org/10.32639/jimmba.v2i2.478

Aziziyah (2021). Peranan Persepsi Manfaat sebagai Mediasi dalam Pengaruh Persepsi Kemudahan Penggunaan dan Kepercayaan terhadap Penggunaan E-commerce pada Aplikasi Traveloka. Jurnal Ilmu Manajemen. Vol 9 no 1.

Budyastuti, T., \& Iskandar, D. (2018). The Influence of Usefulness, Easy of Use and Trust Using ECommerce To User Behaviour (Case Study To Lazada.Com Consumers). Journal of Marketing and Consumer Research, 46, 78-83.

Cnnindonesia.com. (2020). Transaksi E-Commerce Naik Nyaris Dua Kali LIpat Saat Pandemi (https://www.cnnindonesia.com, ekonomi/20201021193353-92-561232/transaksi-e-commercenaik-nyaris-dua-kali-lipat-saat-pandemi. Diakses pada 15 Januari 2021).

Corbitt, B. J., Thanasankit, T., \& Yi, H. (2003). Trust and E-commerce: A Study of Consumer Perceptions. Electronic Commerce Research and Applications, 2(3), 203-215. https://doi.org/10.1016/S1567-4223(03)00024-3

Covid-19.bps.go.id. (2020). Infografis Hasil Survei Sosial Demografi Dampak Covid-19. (https://covid-19.bps.go.id/home/infografis. Diakses pada 21 Agustus 2020).

Dahlberg, T., Mallat, N., \& Öörni, A. (2003). Trust Enhanced Technology Acceptance ModelConsumer Acceptance of Mobile Payment Solutions. In Mobility Roundtable, Stockholm, Sweden: 2003.

Davis, F. D. (1989). Perceived Usefulness, Perceived Ease of Use, and User Acceptance of Information Technology. MIS Quarterly, 13(3), 319-340.

Fatuh, M., \& Widyastuti. (2017). Pengaruh Promosi Penjualan, Perceived Ease of Use dan Perceived Usefulness terhadap Keputusan Menggunakan Transportasi Online (Studi pada Pengguna Uber di Surabaya Pusat). Jurnal Ilmu Manajemen (JIM), 5(4), 1-9. http://jurnalmahasiswa.unesa.ac.id/index.php/jim/article/view/22182

Fransisca, G. (2020). Begini Pergeseran Perilaku Konsumen Baru selama Pandemi Covid-19. Bisnis.com. (https://ekonomi.bisnis.com/read/20200515/12/1240921/begini-pergeseranperilaku-konsumen-baru-selama-pandemi-covid-19. Diakses pada 21 April 2020).

Hadya, Dwi. (2021). Nilai Transaksi E-Commerce Mencapai Rp. 266, 3 Triliun pada 2020. 
Rizky Ramadhany Sito Putri \& Sri Setyo Iriani. Pengaruh Perceived Ease of Use dan Perceived Usefulness terhadap Keputusan Penggunaan Aplikasi Tokopedia melalui Trust sebagai Variabel Intervening

Katadata.co.id. (https://databoks.katadata.co.id/datapublish/2021/01/29/nilai-transaksi-ecommerce-mencapai-rp-2663-triliun-pada-2020. Diakses pada 28 Maret 2021).

Hamid, A. A., Razak, F. Z. A., Bakar, A. A., \& Abdullah, W. S. W. (2016). The Effects of Perceived Usefulness and Perceived Ease of Use on Continuance Intention to Use E-Government. Procedia Economics and Finance, 35(October 2015), 644-649. https://doi.org/10.1016/s22125671(16)00079-4

Hartono, Jogiyanto. (2007). “Model Kesuksesan Sistem Teknologi Informasi”, Yogyakarta: Andi.

Iprice.co.id. (2021). The Map of E-Commerce in Indonesia. (https://iprice.co.id/insights/mapofecommerce/en/. Diakses pada 28 Maret 2021).

Kim, D.J., Ferrin, D.L. and Rao, H.R. 2008. A Trust-Based Consumer Decision Making Model in Electronic Commerce: The Role of Trust, Perceived Risk, and Their Antecedents. Decision Support Systems. Vol. 44 No. 2, pp. 544-64. https://doi.org/10.1016/j.dss.2007.07.001

Lee, C. B. P., \& Wan, G. (2010). Including Subjective Norm and Technology Trust in the Technology Acceptance Model: A Case of E-ticketing in China. SIGMIS Database 41, 4, 40-51. https://doi. org/10. 1145/1899639. 189964.

Lee, M.K.O. Turban, E. 2001. A Trust Model for Consumer Internet Shopping, International Journal of Electronic Commerce. Vol. 6 No. 1, pp. 75-91.

Lee, A. S., \& Luo, X. (2015). Nankai Business Review International Article information: About Emerald www.emeraldinsight.com. Nankai Business Review International, 6(4), 350-363. http://dx.doi.org/10.1108/NBRI-01-2015-0001.

Lestari, I. T. \& Widyastuti, W. (2019). Pengaruh Kepercayaan Dan Kemudahan Terhadap Keputusan Belanja Online (Studi Pada Pengguna Tokopedia). Jurnal Ilmu Manajemen, 7(2), 478-484.

Lin, H. F. (2011). An empirical investigation of mobile banking adoption: The effect of innovation attributes and knowledge-based trust. International Journal of Information Management, 31(3), 252-260. https://doi.org/10.1016/j.ijinfomgt.2010.07.006

M. A. Al-Sharafi, R. A. Arshah, E. A. Abo-Shanab, A., \& N. Elayah, "The Effect of Security and Privacy Perceptions on Customers' Trust to Accept Internet Banking Services: An Extension of TAM. Journal of Engineering and Applied Sciences. Vol. 11, pp. 545-552., 2016.

Mahkota, A. P., Suyadi, I., \& R. (2014). Pengaruh Kepercayaan dan Kenyamanan terhadap Keputusan Pembelian Online (Studi pada Pelanggan Website Ride Inc). Jurnal Administrasi Bisnis, 8(2): $1-7$.

Mensah, I. K., Jianing, M., \& Durrani, D. K. (2017). Factors Influencing Citizens' Intention to Use EGovernment Services: A Case Study of South Korean Students in China. International Journal of Electronic Government Research, 13(1), 14-32. https://doi.org/10.4018/JJEGR.2017010102

Pusparisa, Y. (2020). Bocornya Puluhan Juta Data Pengguna E-Commerce Indonesia. Katadata.co.id. Databoks. (https://databoks.katadata.co.id/datapublish/2020/05/12/bocornya-puluhan-juta-datapengguna-e-commerce-indonesia. Diakses pada 21 April 2020)

Pusparisa, Y. (2020). Pandemi Tingkatkan Penggunaan Aplikasi Digital Asia Tenggara. Katadata.co.id. Databoks. (https://databoks.katadata.co.id/datapublish/2020/08/31/pandemitingkatkan-penggunaan-aplikasi-digital-asia-tenggara. Diakses 10 September 2020) 
Setyo Iriani, S., \& Lestari Andjarwati, A. (2020). Analysis of Perceived Usefulness, Perceived Ease of Use, and Perceived Risk Toward Online Shopping in the Era of Covid-19 Pandemic. Systematic Reviews in Pharmacy, 11(12), 313-320.

Suberi, M., \& Ab, B. (2014). Perceived Usefulness and Trust Towards Consumer Behaviors: A Perspective of Consumer Online Shopping. Journal of Asian Scientific Research, 4(10), 541546.

Suhir, M., \& Suyadi, I. Riyadi.(2014). Pengaruh Persepsi Resiko, Kemudahan dan Manfaat terhadap Keputusan Pembelian secara Daring (Survei terhadap Pengguna Situs website www. kaskus.co. id). Jurnal Administrasi Bisnis, 8 (1), 1-10.

Tokopedia.com (2021). Lebih Dari Sekadar Marketplace. (https://www.tokopedia.com/about/. Diakses pada 28 Maret 2021).

Turban, Efraim, David King, Dennis Viehland, Jae Lee. (2010). Electronic Commerce a Managerial Perspective. International Edition. Pearson Prentice Hall, New Jersey: 2010.

Venkatesh, V., \& Davis, F. D. (2000). Theoretical Extension of The Technology Acceptance Model: Four Longitudinal Field Studies. Management Science, 46(2), 186-204. https://doi.org/10.1287/mnsc.46.2.186.11926

Yusuf Dauda, S., \& Lee, J. (2015). Technology adoption: A Conjoint Analysis of Consumers' Preference on Future Online Banking Services. Information Systems, 53, 1-15. https://doi.org/10.1016/j.is.2015.04.006 